\title{
GONDOLATOK A REGIONÁLIS IDENTITÁSRÓL - IDENTITÁSELEMEK A NYUGAT-DUNÁNTÚLI RÉGIÓBAN
}

\author{
(Ideas about Regional Identity - Elements of Identity in West- \\ Transdanubian Region)
}

\author{
NÁRAI MÁRTA
}

Kulcsszavak:

régió regionális identitás területi kötödés régióépités Nyugat-dunántúli régió

Jelen tanulmány egyrészt a regionális identitás elméleti hátterét mutatja be, valamint a regionális identitásnak a régióépités folyamatában betöltött szerepét taglalja. Másrészt a szerzö a Nyugat-dunántúli régió példáján arra a kérdésre keresi a választ, hogy több mint tí évvel a régiók felülröl vezérelt "megszïletése" utón vajon az ország egyik gazdaságilag legsikeresebb régiójában létezik-e, érzékelhetö-e a regionális identitás, illetve kísérletet tesz ezen identitáselemek azonosítására és bemutatásásra.

\section{Bevezetés}

Önmeghatározásunk fontos részét képezi a területi-térségi hovatartozásunk, melynek definiálásával legerősebb szociális szükségletünket, a valahová tartozás szükségletét elégítjüik ki (Raagmaa 2002). De vajon a térben mekkora földrajzi távolságra terjed(het) ki identitásérzetünk, identitástudatunk? Ez természetesen jelentős mértékben függ attól, hogy hol és milyen kontextusba ágyazottan kell meghatároznunk önmagunkat, azaz például, hogy alapvetỏen lakóhelyünktől, otthonunktól milyen távol definiáljuk magunkat, adott viszonylatban, élethelyzetben, történeti, földrajzi, gazdasági, környezeti vagy éppen szociokulturális összefüggésben területi-térségi hovatartozásunknak mely szintje(i) (pl. település, megye, kultúrtáj, régió, ország, földrész) a legmeghatározóbbak.

Nyilvánvalóan különösen meghatározó települési hovatartozásunk, lokális identitásunk. Az identitás következó területi szintjének jelzésekor természetes módon fejezzük ki azt is, hogy mely megyében élünk. A regionális identitás esetében azonban általában azt tapasztalhatjuk, hogy az még nem fejlődött olyan szintre, hogy készségekben és emocionálisan is hasson, mozgósítani tudjon az egyének és a közösségek világában (Bokor é.n.). Egyes felmérések szerint a kilencvenes években a lokális identitás felerôsödött, a megyei identitás gyengült, regionális identitás viszont szinte nem létezett (Bỏhm 2000). Ez utóbbin nincs mit csodálkoznunk, hiszen Magyarországon a régiók megszerveződése - több elhalt kísérlet után ismét - a kilencvenes években indult el, ráadásul egy mesterségesen generált, felülröl vezérelt 
Nárai Márta : Gondolatok a regionális identitásról. - Identitáselemek a Nyugat-dunántúli régióban. Tér és Társadalom 23. évf. 2009/4. 137-159. p.

folyamatként és nem alulról építkezve. A társadalomban nem volt jelen a régióról folyó diskurzus (Varró 2004), és nem voltak meg a hagyományai a régióban való gondolkodásnak sem, legalábbis a „régió” szó explicit használatának értelmében.

Régió és regionális identitás azonban feltételezik egymást, egyrészt ténylegesen mủködỏ régió nélkül nem alakul(hat) ki regionális tudat, másrészt létező regionális identitás, társadalmi kohézió szükséges ahhoz, hogy egy régió sikeres legyen, képes legyen a fejlödésre (Hegyi 2007), de egyáltalán ahhoz is, hogy egy térség valóban, társadalmi, gazdasági és politikai értelemben is, régióvá váljon (Raagmaa 2002). Ezek ismeretében mindenképpen feltételezhetjük, hogy a funkcionálisan is müködö régiók esetében előbb vagy utóbb megjelenik a régióval való azonosulás. Ahol azonban egy régió elhatározás vagy politikai döntés és nem alulról táplálkozó kezdeményezés vagy különleges történelmi körülmények szülötte, ott jelentős intézményi, kulturális és anyagi ráfordítás, valamint hosszú idő szuikséges ahhoz, hogy a társadalom különböző szereplöi - a lakosság, az önkormányzatok, a gazdasági és más intézményi szereplők - körében kialakuljon a régiós térhez való kötỏdés, a regionális tudat, regionális identitás. Az összetartozás hangsúlyozása, a valóságos együttmüködések nagyban segít(het)ik ezt a folyamatot.

\section{A regionális identitás, területi kötödés fogalmi háttere}

A térségekhez kötődő identitás, melyet a nemzetközi szakirodalomban egységesen regionális identitásnak neveznek (Paasi 2000; 2002; 2003; van Houtum-Lagendijk 2001; Raagmaa 2002; Landaboso 2003), az utóbbi évtizedben vált meghatározó fogalommá, bár a küllföldi szakirodalomban nem ismeretlen területról van szó, a helyi illetve a regionális kötődés okai és következményei kutatás tárgyát képezték már a hatvanas években (pl. angolszász területeken, illetve a volt NSZK-ban). Magyarországon az elmúlt időszak regionalizálási törekvéseinek, folyamatainak köszönhetően nőtt meg a téma iránti érdeklödés.

Az identitás a régiófogalom része, méghozzá annak domináns eleme, hiszen éppen a közös identitás, a régió és annak lakói közötti harmónia, egység az, ami a régiót megkülönbözteti az egyszerü fizikai tértől (Raagmaa 2002), ami úgymond „személyiséget" kölcsönöz az adott térségnek. A közös identitás társadalmi, területi, történelmi és kulturális gyökerekre nyúlik vissza (Paasi 2003), megjelenhet eszmékben, kulturális elemekben, sajátos dialektusban, hagyományokban, természeti-táji, illetve épített környezetben, de akár gazdasági sikerességben is. A regionális identitás egyszerre tudatos és emocionális azonosulás, kötódés egy térséghez (régióhoz), amely történelmi és területi szocializációs folyamat eredményeként jön létre (Raagmaa 2002). Az emocionális kötődés erösen függ pl. attól, hogy mennyi ideje él valaki az adott helyen, illetve milyen formában és menyire kötődik az ott élőkhöz.

A helyhez való kötődés erösségében, illetve a területi identitás kialakulásában már viszonylag korán - hetvenes évek - hangsúlyozták a társadalmi dimenzió fontosságát, 
Nárai Márta : Gondolatok a regionális identitásról. - Identitáselemek a Nyugat-dunántúli régióban. Tér és Társadalom 23. évf. 2009/4. 137-159. p.

TÉT XXIII. évf. 2009 a 4

Gyors ténykép

139

az azonos érdekek, értékek, illetve a társadalmi kapcsolatok, valamint a környezeti elemek meghatározó voltát (Relph 1976 - idézi Palkó 2009, 197).

Ipsen (1993) a régió egyediségét (különbözzék másoktól - „kontúr”); az összetartozás érzését, azt, hogy a régiót egészként fogják fel az ott élők (koherencia); valamint az összetettséget, a térség sokszínúségét (komplexitás) tartja meghatározónak a regionális identitás kialakulásában. Ezek a tényezők gyakorlatilag az 'egy régióhoz való kötődés érzésének' az előfeltételét jelentik.

Blotevogel és szerzőtársai (1989) a regionális identitás különböző szintjeit (fokát) határozták meg:

1) Kognitív szint: a régió identitása, azaz egy régió azonosíthatósága, sajátossága - egy adott térség régióként való észlelése, érzékelése, az emberek tudatában a régió azonosítása, mint önálló, egyedi területi egység.

2) Affektív (érzelmi) szint: a régió, mint a személyes identitás szempontja jelenik meg, azaz az egyén énképének integráns részévé válik a területi (régiós) hovatartozása - összetartozás érzése.

3) Konatív szint: a régió, mint a szociális identitás szempontja jelenik meg - a régió az ott élók mi-tudatának szerves alkotóelemévé válik (kialakulásában meghatározó a régióval való elégedettség is).

A legújabb megközelítések szerint a regionális identitás három, egymással szorosan összefonódó dimenzióban ragadható meg: a stratégiai, a kulturális és a funkcionális identitásdimenziókban (van Houtum-Lagendijk 2001). Mindez azt is jelenti, hogy egy régiónak akkor lesz meg a saját identitása, ha különbözik más régióktól a stratégiai terveit illetően (stratégiai identitás), a kulturális vagyonát tekintve (kulturális identitás), illetve funkcionális tevékenységeiben/dimenziójában (funkcionális identitás).

A stratégiai identitás azt jelenti, hogy az adott régió lakosságának, intézményi, szervezeti szereplőinek legyenek közös céljai, legyen egy közös, dokumentált jövőképe az adott területre vonatkozóan, hiszen részben ezzel, ez által válik különlegessé a terület. Ez a közös stratégia mindenki számára - régión belüliek és kívüliek számára egyaránt - nyilvánvalóvá teszi, hogy melyek azok az elképzelések, célok, amelyeket a régióban élók preferálnak, követni szándékoznak.

A regionális identitás kulturális dimenziỏja azt a folyamatot jelenti, amelyen keresztül a közös öntudat, a valahová tartozás érzése (ki)fejlödik, erősödik. Értékalapjai, elemei általában azok a közös szimbólumok, amelyek segítenek felismerni az egyéneknek hovatartozásukat, és kifejezik a régió egységét.

A funkcionális identitás (dimenzió) a régión belüli társadalmi-gazdasági együttmüködéseket, kapcsolatokat és kötelékeket jelenti.

A regionális identitás e három eleme nagyon szoros kapcsolatban van egymással. A kulturális és a funkcionális identitás kettős szerepet játszik, egyrészt segítik a régióformálást a történelmi múlt és a meglévő kapcsolatrendszer alapján, másrészt hatást gyakorolnak a jövő stratégiai irányvonalára (Lukovics 2004). 
Nárai Márta : Gondolatok a regionális identitásról. - Identitáselemek a Nyugat-dunántúli régióban. Tér és Társadalom 23. évf. 2009/4. 137-159. p.

\section{A regionális identitás szerepe a régióépitésben}

A tér, annak minden dimenziója társadalmi konstrukció (Paasi 2000; Faragó 2007; Nemes Nagy 2009), így a területi folyamatok sohasem lehetnek függetlenek a társadalmi, kulturális és természeti folyamatoktól. Varró (2004) hangsúlyozza, hogy az egyes térkategóriák, így a régió is bizonyos kontextuson belül nyernek jelentést, és nemcsak nyelvi, hanem adott történelmi keretben kell azt értelmezni, hiszen amennyiben a régiót társadalmi konstrukciónak fogjuk fel, akkor egyúttal történelmi képződménynek is kell tekintenünk.

Paasi (2000) a régiót, mint társadalmilag megkonstruált teret vizsgálva jutott el a regionális identitás fontosságának hangsúlyozásához, melynek kiemelt szerepet tulajdonít a régiók intézményesítésében. A régióépítés egy folyamat, melynek négy lépését különíti el:

1) A területi struktúra kialakítása,

2) Közös szimbólumok megformálása,

3) Regionális intézmények, kapcsolatok kialakítása,

4) Regionális identitás kialakulása (Paasi 2000).

A folyamat során gyakorlatilag a van Houtum és Lagendijk (2001) szerzőpáros által leírt identitáselemek (stratégiai, kulturális, funkcionális dimenzió) kialakulásáról van szó. A Paasi által elkülönített lépések egymással általában párhuzamosan mennek végbe, illetve ugyanazon folyamatnak különbözö oldalait jelentik a gyakorlatban (Lukovics 2004).

A régióformálásban meghatározó lépés a területi struktúra kialakítása, azaz az a mozzanat, amikor a régió azonosíthatóvá válik, mint területi egység. Ehhez elengedhetetlenül szükséges valamiféle határok (nem feltétlenül közigazgatási határok) kijelölése, megkonstruálása, ami behatárolja azoknak a körét, akik a régióhoz tartoznak.

A régió lehatárolása, a „mi” és „ő" definiálása mellett a régió identifikációs folyamatában kiemelkedő jelentőségủ a régióra jellemzỏ szimbólumrendszer (pl. név, szlogen, rendezvények stb.) megformálása. A szimbólumok kifejezik a régió egységét, és az összetartozást szimbolizálják, segítenek a közös imázs felépítésében. Paasi (2003) azonban hangsúlyozza, hogy bár ezek fontosak a közös tudat formálásában, de a regionális identitás lényegét nem a szimbólumok jelentik, hanem sokkal inkább a tényleges társadalmi, kulturális együttmủködések és a különféle közös akciók, események képezik. Ez utóbbiak átvezetnek minket a régióformálás harmadik mozzanatához, nevezetesen az intézmények kialakításához, melyek alatt gyakorlatilag nemcsak a formális intézményeket és szervezeteket kell érteni, hanem mindenféle kapcsolatot, együttmúködést, amelyek a régióban az emberek, illetve a különböző szervezetek, intézmények között létrejöhetnek. Az intézmény- és kapcsolatformálás segít létrehozni a régió belső kohézióját, jelentős mértékben hozzájárul az identitás, a regionális öntudat kialakulásához, fenntartásához és erősitéséhez. A fizikai térből pedig igazából akkor jön létre igazi régió, amikor már kialakul 
Nárai Márta : Gondolatok a regionális identitásról. - Identitáselemek a Nyugat-dunántúli régióban. Tér és Társadalom 23. évf. 2009/4. 137-159. p.

TÉT XXIII. évf. 2009 - 4

Gyors ténykép

141

a regionális identitás, nemcsak a szimbólumok és a kommunikáció szintjén (kommunikált [ideális] identitás), hanem az már a civil társadalomban is létezik az emberek azonosulása révén, és megnyilvánul(hat) bizonyos szereplők aktivitásán keresztül (tényleges identitás =regionális öntudat) (Lukovics 2004). Nem a tér puszta léte teremti meg tehát a régiót, hanem az ott élők töltik meg tartalommal (Hegyi 2007).

A folyamat egyes lépései összekapcsolhatók a regionális identitás Blotevogel és szerzötársai (1989) által felállított - az előző fejezetben említett - különbözö fokozataival: Ahhoz, hogy régióként észleljenek, érzékeljenek az emberek egy térséget (kognitív dimenzió), szükséges annak területi egységként való lehatárolása, azonosíthatósága. Az összetartozás megfogalmazása, kinyilvánítása - akár szimbólumok, akár együltmüköđések, kapcsolatok, közös események révén - szükséges ahhoz, hogy a régió megjelenjen a személyes identitás szempontjaként, az egyén énképének részévé váljon (érzelmi dimenzió). Végül ahhoz, hogy a regionális identitás az emberek és más szereplök cselekvéseiben is ,aktivizálódjon”, elengedhetetlen, hogy a régió az ott élök mi-képének szerves részévé váljon (konatív dimenzió).

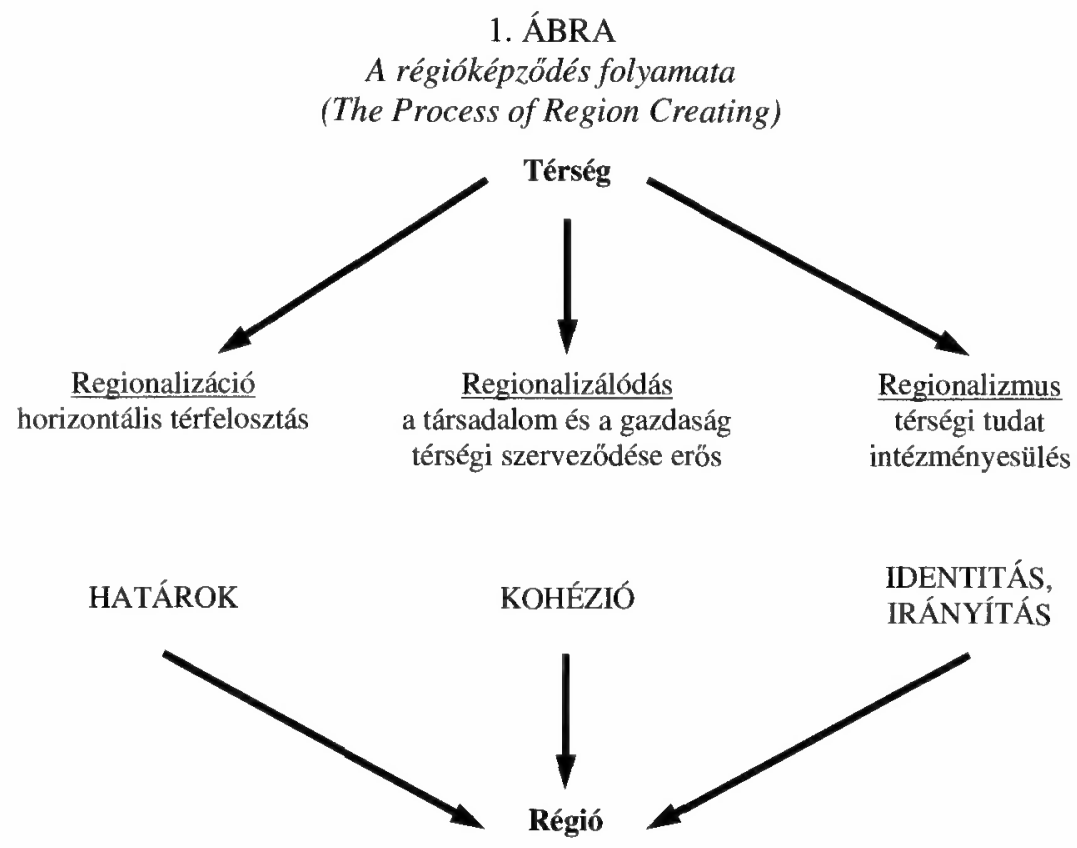

Forrás: Nemes Nagy (2009, 192).

A magyar szakirodalomban (Agg-Nemes Nagy 2002; Lengyel-Rechnitzer 2004; Nemes Nagy 2009) a régiónak, mint önálló területi-társadalmi entitásnak a létrejöttét három egymással kapcsolatban álló és gyakran egymással párhuzamosan haladó folyamatból álló modellként írják le. A modell komponensei:

- regionalizáció: az adott terület (régió) határvonalakkal való 'kijelölése'; 
Nárai Márta : Gondolatok a regionális identitásról. - Identitáselemek a Nyugat-dunántúli régióban.

Tér és Társadalom 23. évf. 2009/4. 137-159. p.

142 Gyors ténykép

TÉT XXIII. évf. 2009 - 4

- regionalizálódás: társadalmi-gazdasági feltételek mellett lezajlódó homogenizálódás, az összetartozás (kohézió) erősödésének folyamata - térségi szerveződés reálfolyamata;

- regionalizmus: a regionális identitás és az intézményesülés, irányítási rendszer létrejöttének átfogó folyamata (Nemes Nagy 2009) (1. ábra).

Mindegyik vázolt modellben egyöntetủen hangsúlyos elem az identitás, az emberek gondolkodásában megfigyelhetö összetartozás, régiótudat, mely egyrészt eredménye, másrészt feltétele is a régióképződésnek.

\section{A regionális identitás hozzájárulása a régió sikerességéhez}

Bár nehéz meghatározni, hogy az identitás pontosan mit is tartalmaz, és hogyan befolyásolja a kollektív cselekvést, napjainkban egyre nyilvánvalóbbá válik, hogy gazdasági hatótényezőként, sikerességi faktorként lehet vele számolni (Garai 1998; Lengyel 2000). Ipsen (1993) már a kilencvenes évek elején a regionális fejlódés egyik előfeltételeként említi a regionális identitást, és hangsúlyozza, hogy az endogén potenciálok vagy a regionális versenyképesség javítása ezáltal szociálpszichológiai és kulturális tényezőhöz kötődik. A regionális identitás egyrészt segít aktivizálni a helyi eróket a gazdaságfejlesztés számára, növeli személyes cselekvéseiket és hozzájárulásukat ahhoz, hogy a közös célokat elérjék (Lukovics 2004), másrészt képes arra, hogy a térség kulturális és egyéb sajátosságait kihangsúlyozza, hozzájáruljon a régió jó hírnevéhez, és ezáltal befektetőket és felkészült munkaerôt vonzzon a térségbe (Raagmaa 2002) (2. ábra). Ebben a megközelítésben már nem egyszerúen a régióhoz való kötődést, a hellyel való azonosulást értik e fogalom alatt, hanem a gazdasági folyamatok pszichológiai-szociálpszichológiai közvetítójeként tekintenek rá (Garai 2003).

Az erős regionális identitással rendelkező régiókban a népesség szívesen él az adott térségben, erős lokálpatriotizmus jellemzi őket, nyitottak a térség fejlesztésével kapcsolatos elképzelésekre, társadalmi aktivitásuk magas. Ezekben a régiókban bizonyos speciális tényezők ${ }^{1}$ megléte esetén a magas szintü társadalmi kohézió lehetôvé teszi, illetve elősegíti az innovativitást, ami által a régió képes a gazdasági, illetve a társadalmi, kulturális fejlődésre. Mindez tovább növeli a régió imázsát és jó hírnevét, a térség nemcsak az ott élők, hanem mások számára is egyre vonzóbb lesz, újabb és újabb betelepülők (befektetők, képzett munkaerő) letelepedését ösztönzi, ami további sikereket eredményez. Ellenben egy gyenge regionális identitással rendelkező régió nem túl vonzó sem az ott élők, sem a régión kívüli emberek, cégek számára, így betelepuilők nem törekszenek a térségbe. Ha mégis sikerül befektetőket a térségbe csábítani, ôk elsősorban vagy az olcsó munkaerỏ vagy természeti kincsek miatt jönnek, lokális beágyazódásuk a gyenge társadalmi kohézió miatt nem várható, így máshol felkínált kedvezőbb lehetőségek esetén elhagyják a régiót (2. ábra).

(Az ábra részletesebb elemzését lásd Lukovics [2004, 223-225]). 
Nárai Márta : Gondolatok a regionális identitásról. - Identitáselemek a Nyugat-dunántúli régióban. Tér és Társadalom 23. évf. 2009/4. 137-159. p.

\section{2. ÁBRA}

A regionális identitás szerepe a gazdasági fejlödésben

(The Role of Regional Identity in Economic Development)

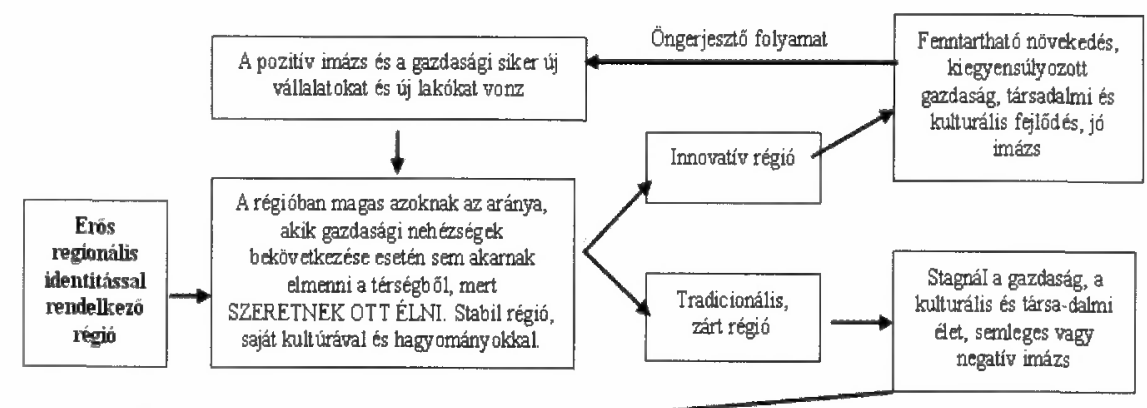

Kiáramlás a régióból

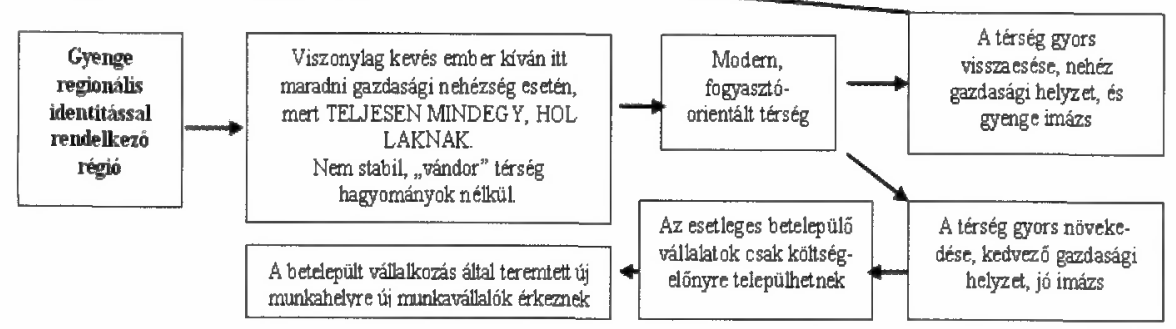

Forrás: Raagma (2002) alapján Lukovics (2004, 224).

A regionális identitás közvetetten, a társadalmi kohézión keresztül hat egy térség fejlődésére.

$\mathrm{Az}$ a régió, ahol erős a regionális identitás, rendelkezik erős belső kohézióval, képes arra, hogy a külső hatásokat befogadja, átalakítsa, feldolgozza oly módon, hogy az a térség és az ott élők hasznára váljon, illetve képes arra, hogy sajátosságai segítségével ahhoz hozzátegyen, és a hatásokat közvetítse másfelé is. Ezek a hatások érvényesülhetnek akár gazdasági sikerességen, társadalmi, kulturális fejlódésen, akár civil aktivitáson keresztül is. Amennyiben a régió belsö kohéziója hiányában nem képes a kívülről érkező impulzusokat sajátosságainak megfelelően adaptálni, akkor a hatások átfutnak rajta anélkül, hogy az ott élők életére befolyással lennének, ami egyben azt is jelenti, hogy a régiónak nincs jelentős szerepe az ott élők életében (Hankiss 2005) (3. ábra).

A különböző létező vagy megszervezett földrajzi terekhez, így akár a településhez, akár a megyéhez vagy a régióhoz való kötődés minősége, belső harmóniája, a „mi tudat” erőssége alapvetően befolyásolhatja tehát az ott élők életminőségét, a gazdasági, társadalmi, területi kihívásokra adott, a helyi társadalom által megfogalmazott válaszlehetőségeket, reakciókat, a térség megtartó erejét, az emberek és más társadalmi-gazdasági szereplők térbeli cselekvéseit (pl. mobilitás). 
Nárai Márta : Gondolatok a regionális identitásról. - Identitáselemek a Nyugat-dunántúli régióban.

Tér és Társadalom 23. évf. 2009/4. 137-159. p.

\section{3. ÁBRA}

A társadalmi kohézió szerepe a fejlödésben

(The Role of the Social Cohesion in Development)
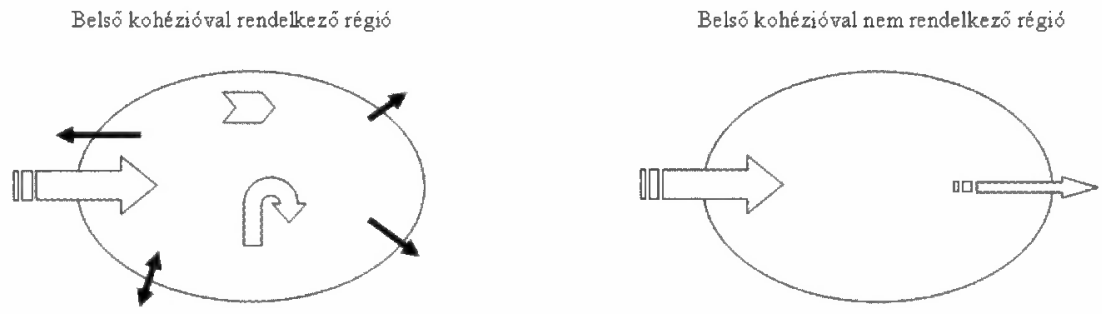

Forrais: Hankiss (2005).

\section{Identitáselemek a Nyugat-dunántúli régióban}

Vajon alig több mint tíz évvel a régiók ,,megszületése” után létezik-e, érzékelhető-e regionális identitás az ország egyik gazdaságilag legsikeresebb régiójában? Sikeres volt-e a felülről elindított régióalakítási folyamat, azaz a tér megtöltődött-e kollektív tartalommal, kialakult-e a társadalmi kohézió, a regionális identitástudat, az emberek gondolkodásában jelen van-e a régió valamiféle reprezentációja, avagy fellelhetők-e az említett tényezők bizonyos elemei a Nyugat-dunántúli régióban annak bizonyítékául, hogy e régió nemcsak egy földrajzi kategória, hanem annál jóval több, társadalmi, gazdasági egység?

E kérdések megválaszolására teszünk kísérletet tanulmányunk további részében.

Magyarországon a régiók megalakulása nem alulról induló kezdeményezésként, hanem politikai döntés eredményeként indult meg. A területfejlesztésröl és területrendezésről szóló 1996. évi XXI. törvény által nevesített területfejlesztési-statisztikai régiók nem anyagi mivoltukban léteztek, hanem elsődlegesen kommunikatív úton jöttek létre, diszkurzív képződmények voltak. E két „képzési-képződési mód” azonban kölcsönösen hat egymásra (Varró 2004, 82): a folyamatos kommunikációnak fontos szerepe van az új térkategória (régió) tudatosításában, illetve a hozzá tartozó jelentéstartalmak formálásában. A média, az üzleti szféra, a tudományos élet és az oktatás szereplöi fontos szerepet töltenek/tölthetnek be ebben a folyamatban. Idövel, a jelentéssel való „megtöltés” kapcsán az emberek, illetve más társadalmi szereplök térszemléletében már megjelenik a régió (észlelés és közlés eszköze lesz). A regionális identitás kialakulása azonban csak akkor várható, ha az egyének megértik és átérzik a régió, a régióban való gondolkodás jelentőségét és ez valamiképp mindennapi térkezelésüket is áthatja (Varró 2004). A régió ekkor már egy olyan terület, amelyet bár nem lehet közvetlenül megélni, de szimbolikus jelleggel beépül az emberek tudatába (Bourdieu 1985). A regionális identitás kiépülése, kiépítése 
Nárai Márta : Gondolatok a regionális identitásról. - Identitáselemek a Nyugat-dunántúli régióban. Tér és Társadalom 23. évf. 2009/4. 137-159. p.

TÉT XXIII. évf. 2009 - 4

Gyors ténykép

145

egyébként is, de történeti, kulturális tradíciók és valós társadalmi együttmüködések híján még inkább hosszú időt igénylő fejlődés során valósulhat meg.

A Nyugat-dunántúli régió esetében gyakran hallani, hogy az nem egy koherensen összetartozó térség, nincsenek közös gyökerei és a gyenge észak-déli közlekedési kapcsolatok sem segítik az összetartozás érzését. Van azonban néhány olyan közös történelmi, illetve földrajzi vonás, amely ennek a térnek az összetartozását mutatja, illetve erôsíti. Ilyen pl. a Borostyánkő-út, amely a római kor híres kereskedelmi útvonala volt, vagy ilyen a régió nyugatisága, amely gyakorlatilag a történelem minden szakaszában, a honfoglalástól egészen napjainkig politika-földrajzi értelemben egységes területként jeleníti meg ezt a területet. Ez a térség az ország nyugati határ vidéke, őrvidéke volt. A II. világháborút követỏen itt húzódott a Vasfüggöny, a politikailag kettéváló Európát szétválasztó határ, ami az itt élők számára a nyugatiságot az elzártságban jelenítette meg. A rendszerváltás után pedig éppen ez a nyugatiság vált e térség előnyévé, így vált a betelepuilö nyugati tỏke egyik fô célterületévé és az uniós határ menti programok (Interreg) első hazai haszonélvezőivé.

A nemzetközi szakirodalomban leírt régióépitési folyamatot (Paasi 2000) nézve, gyakorlatilag a Nyugat-dunántúli régió területi lehatárolásával szinte egyidőben elkezdődött a regionális intézmények kiépítése (pl. Nyugat-dunántúli Regionális Fejlesztési Tanács megalakulása), különböző együttmủködések megszerveződése. Bizonyos dekoncentrált állami, alapvetően közigazgatási, valamint egyes közszolgáltatási szervezetek esetében ez a folyamat már korábban elkezdödött, és ekkor már előbbre is járt (funkcionális dimenzió részei).

Következő lépésben megszuilettek a régió szimbólumai (internetes honlap, logó, szlogen [Nyugat-Dunántúl a kezdeményezések régiója]). Elindult és folyamatos a régió kommunikálása is, egyrészt kifelé - az országos sajtóban hírek jelennek meg a régióról -, másrészt befelé, az itt élök felé - a régión belül az egyes megyei napilapok számos regionális szintủ eseményrỏl számolnak be, illetve egyre több hírt, információt közölnek a régióba tartozó más megyebeli településekröl, eseményekről is -, jelezvén és egyben erósítvén is az összetartozást, az egységet (kulturális dimenzió). Időközben megfogalmazásra került a régió területfejlesztési stratégiája is, lefektetve a közös célokat, preferenciákat, meghatározva a térség egyediségét (stratégiai dimenzió).

A közvetített képekböl, imázsokból kitủnik, hogy a régió mind kifelé, mind befelé alapvetỏen pozitív képet sugároz magáról gazdaságilag, társadalmilag egyaránt. Mindezek hozzájárulnak ahhoz, hogy kialakítsák, illetve erősítsék, fejlesszék a regionális identitástudatot, hiszen egy vonzó régió képe alakul ki az emberek fejében a Nyugat-Dunántúlról (Hegyi 2007), ahol jó élni, amivel jó azonosulni.

Vajon a kommunikált regionális identitás mellett - azon túl - a tényleges regionális öntudat (identitás) is kialakult már, az itt élö emberek, különböző társadalmi, intézményi stb. szereplök önmeghatározásában helyt kapott-e a régióval való azonosulás? E kérdés megválaszolásában segítséget nyújtanak azok a kutatások, amelyek a régió lakossága vagy a társadalom más szereplöi körében - többek között - a társadalmi kohézió, a régióhoz való kötődés, a régiótudat létének a feltérképezésére 
Nárai Márta : Gondolatok a regionális identitásról. - Identitáselemek a Nyugat-dunántúli régióban. Tér és Társadalom 23. évf. 2009/4. 137-159. p.

(is) törekedtek, így empirikus adatokkal szolgálnak számunkra². A vizsgálatok közül mindenképpen ki kell emelnünk a régió lakossága körében 2000-ben, illetve 2008-ban folytatott reprezentatív kérdőíves felméréseket. A 2000-es lakossági felmérést az MTA RKK Nyugat-magyarországi Tudományos Intézete végezte 500 fö körében „A lakosság gazdasági helyzete és várakozásai” címü kutatás keretében. A másik kutatás 2008. év végén a Nyugat-dunántúli Fejlesztési Tanács és Ügynökség szervezésében, több mint 1100 fö körében a régióidentitás, a régió ügyeiben való jártasság és az egyes kommunikációs csatornák igénybevételének vizsgálatára irányult, és gyakorlatilag naprakész adatokkal szolgál a vizsgált kérdéskört illetően.

\section{A régió ismertsége}

Mivel a régió és a régiótudat szorosan összefüggő jelenségek, először vizsgáljuk meg, hogy mennyire elfogadott, illetve mennyire ismert a régió struktúrája.

1998-ban, a régió megszerveződését követően egy, a régiók belső kohézióját vizsgáló kutatás során a regionális fejlesztésben érdekelt szereplök (polgármesterek, megyei közgyülési elnökök, kistérségi társulások vezetői, pártpolitikusok stb.) körében végzett interjúk tapasztalata szerint a Nyugat-dunántúli régióban a régió földrajzi kereteit, kiterjedését (határait) tekintve általában egyetértés uralkodott (4. ábra), ami valamiféle kohézió meglétét is mutathatta volna. Bár összességében a megkérdezettek kétharmada teljes mértékben egyetértett azzal, hogy Győr-Moson-Sopron, Vas és Zala megye alkosson egy régiót, jelentös megyénkénti eltérések mutatkoztak az egyetértés/egyet nem értés mértékében. Vasban és Zala megyében volt a leginkább, míg Győr-Moson-Sopron megyében volt a legkevésbé elfogadott a felülről vezérelt struktúra; ez utóbbi megyében egyet nem értőket is találtunk. Elsődlegesen Zala megye régióhoz tartozását kérdőjelezték meg interjúalanyaink, illetve más megyéket (vagy azok egy részét) láttak volna szívesen a régió határain belül (Nárai 1998).

A lakosság régióképének vizsgálata során elöször vizsgáljuk meg azt, hogy menynyire vannak az emberek tisztában azzal, hogy lakóhelyük mely régióban van, ismerik-e annak nevét, majd nézzük meg azt is, hogy tudják-e annak pontos lehatárolását, azaz tudják-e, hogy a Nyugat-dunántúli régió mely megyéket foglalja magában. Ahol az emberek tisztában vannak a régió határaival, ismerik annak struktúráját, az azt is jelenti, hogy gondolati síkon már jelen van a régió reprezentációja.

A megkérdezettek döntő többsége $(73,5 \%)$ már az évtized elején is, azaz néhány évvel a régiók ,kialakítása" után tudta, hogy lakóhelye a Nyugat-dunántúli régióhoz tartozik, napjainkra ez az arány még magasabb értéket ért el, a válaszadók 82\%-a tisztában van azzal, hogy mely régióban él. A 2000 -es adatfelvétel azonban jelentős eltéréseket mutatott e téren a szerint, hogy a régió mely megyéjében él a megkérdezett. A Vas megyében élö válaszadók körében a régióátlagot jóval meghaladó (93\%), míg a Zala megyében élök körében azt jelentős mértékben alulmúló arányban $(58,4 \%)$ találtuk azokat, akik megbízható tudással bírtak a régió megnevezését illetően. Egyébiránt az is elmondható, hogy az iskolai végzettség is jelentős 
Nárai Márta : Gondolatok a regionális identitásról. - Identitáselemek a Nyugat-dunántúli régióban. Tér és Társadalom 23. évf. 2009/4. 137-159. p.

TÉT XXIII. évf. 2009 - 4

Gyors ténykép

147

befolyásoló erővel bír e tudásra, míg a kevesebb, mint nyolc általános iskolával rendelkezők fele, addig az érettségizetteknek már háromnegyede, a diplomásoknak viszont már $90 \%-\mathrm{a}^{3}$ tudta, hogy lakóhelyük mely régió részét képezi.

\section{4. ÁBRA}

A Nyugat-dunántúli régió lehatárolásával való egyetértés aránya, 1998

(The Share of Understanding with Delimination of West-Transdanubian Region)

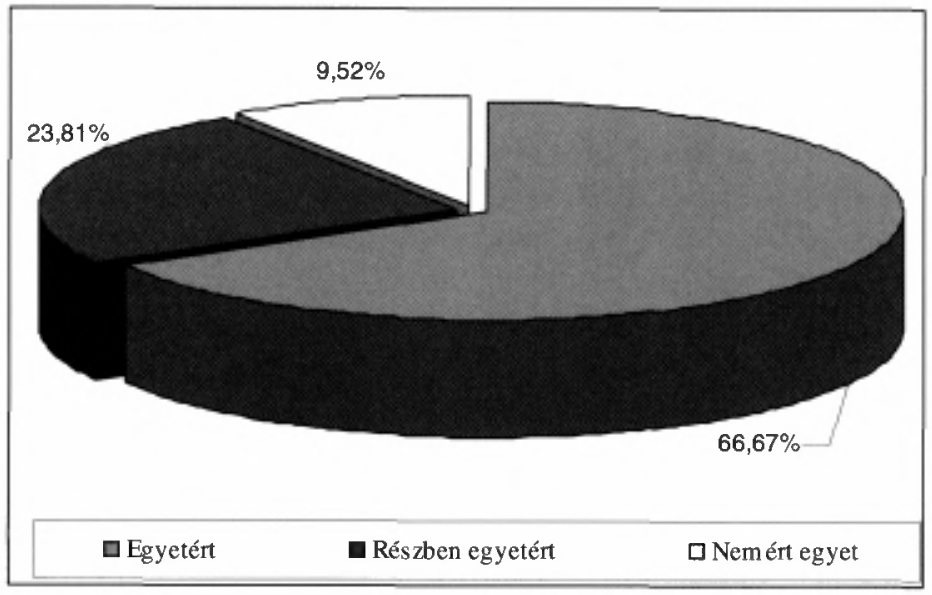

Forrás: Nárai $(1998,6)$.

Bár mindkét felmérésben az derült ki, hogy a válaszadók többsége tudja, hogy lakóhelye a Nyugat-dunántúli régióhoz tartozik és ismeri is pontosan a régió nevét, azt már lényegesen kevesebben tudják saját kútföböl, hogy valójában mely megyék alkotják a nevezett térséget. Hogy mennyire nem alakult ki határozott régiókép az emberekben, nagyon jól mutatja, hogy a 2008 végén végzett felmérés során a „Mely megyék tartoznak Ön szerint az Ön lakóhelye szerinti régióhoz?" kérdésre adott válaszok döntő többségében említésre kerültek ugyan a régiót alkotó megyék valamilyen kombinációban, de csupán a válaszadók 7\%-a (!) tudta helyesen, hogy a Nyugatdunántúli régió az konkrétan Győr-Moson-Sopron, Vas és Zala megye hármasát jelenti (Pakainé Kováts-Bednárik 2009). Egy 1998-ban, polgármesterek körében végzett vizsgálat tapasztalatai hasonlóan kedvezötlenek voltak, akkor is csupán a megkérdezettek 6\%-a adott helyes választ a kérdésre (Szörényiné Kukorelli 1998).

Abban az esetben, amikor a válaszadóknak nem maguktól kellett megadniuk a régiót alkotó megyék körét, hanem elöre megnevezett megyékról kellett eldönteniük, hogy azok vajon a Nyugat-dunántúli régióba tartoznak-e vagy sem, lényegesen kedvezőbb volt a régió összetételének az ismertsége. A segített ismertség során Vas, Zala és Győr-Moson-Sopron megye régióhoz tartozása többnyire ismert volt a válaszadók elött, de így is akadtak olyanok - nem is kevesen -, akik más megyéket is a régióba tartozónak véltek (5. ábra). 
Nárai Márta : Gondolatok a regionális identitásról. - Identitáselemek a Nyugat-dunántúli régióban. Tér és Társadalom 23. évf. 2009/4. 137-159. p.

\section{5. ÁBRA}

A Nyugat-dunántúli régió összetételének ,segített” ismertsége - az elóre megadott megyéket a Nyugat-dunántúli régióba sorolók aránya (\%)

(The „Aided" Reputation of Composition of West-Transdanubian Region-the Share of Respondents who ordered the Prelisted Counties to West-Trasndanubian Region)

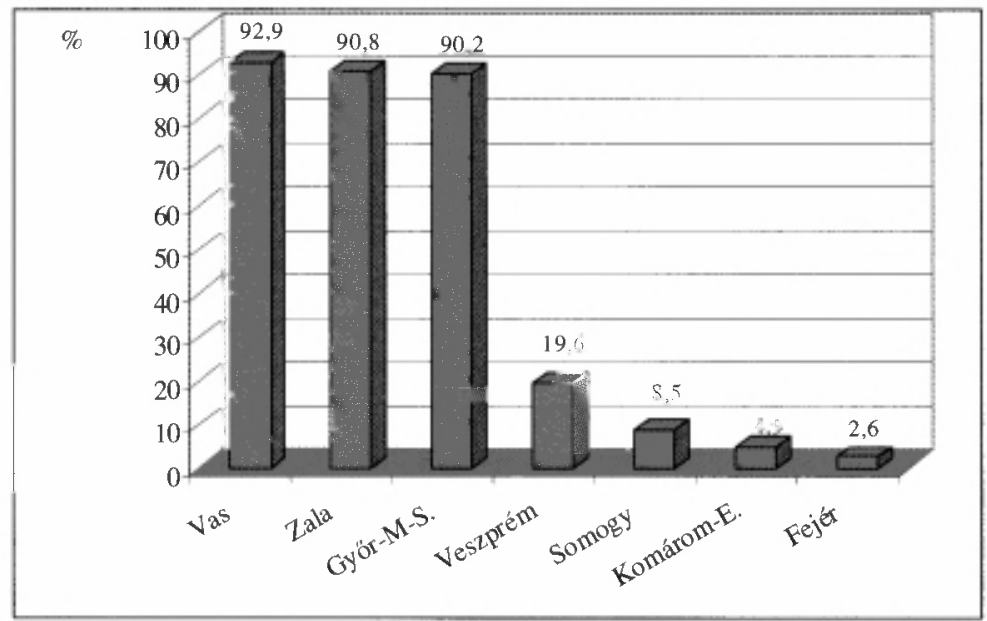

Forrás: Pakainé Kováts-Bednárik (2009, 22-25) alapján saját szerkesztés.

A régió önmeghatározásában, identifikációs folyamatában meghatározó jelentöségü a régió egységét, összetartozását kifejezö szimbólumok megalkotása/megtalálása (Paasi 2000) és kommunikálása a lakosság és más társadalmi szereplők felé. Ezek a szimbólumok segítenek a közös tudat formálásában, a regionális identitás kialakulásában, fejlődésében. Ehhez azonban az kell, hogy a lakosság ismerje, elfogadja, értse a szimbólumrendszer egyes elemeit, illetve egyetértsen azokkal. A Nyugat-dunántúli régióban is megszuilettek a régió alapvetó szimbólumai (pl. logó, szlogen), sajnálatos módon azonban azokat csak a lakosság kisebb része ismeri. A megkérdezetteknek csak kevesebb, mint negyede látta már biztosan a régió logóját, közel fele viszont még sohasem találkozott azzal. A válaszadók $26 \%$-a pedig bizonytalan, nem tudta biztosan, hogy látta-e azt vagy sem (Pakainé Kováts-Bednárik 2009, 153). Ez egyben azt is jelenti, hogy ha látták is a régió jelképét valahol, az nem volt rájuk akkora hatással, hogy arra később emlékezzenek. A régió jelmondatának (szlogen) ismertségére vonatkozóan nem kérdezték a felmérés résztvevöit, de feltételezhetö, hogy az még kedvezőtlenebb lenne, mivel egy szövegre visszaemlékezni nehezebb, mint egy képi elemre. Ez mindenképpen felveti a szimbólumok kommunikálásának fontosságát, illetve felmerül az a kérdés is, hogy jelenlegi formájában mennyire hatásos a logó kifejezó és megragadó ereje. 
Nárai Márta : Gondolatok a regionális identitásról. - Identitáselemek a Nyugat-dunántúli régióban. Tér és Társadalom 23. évf. 2009/4. 137-159. p.

TÉT XXIII. évf. 2009 @ 4

Gyors ténykép

\section{Az emberekben, a különbözö szereplökben élö régiókép}

A kialakuló régióképet és így a regionális öntudatot is jelentős mértékben befolyásolja az, hogy mit is jelent az emberek számára maga a régió fogalma, miként, hogyan értelmezik ezt a szót, mit értenek alatta?

A területfejlesztéssel kapcsolatban álló szakemberek többsége 1998-ban régió alatt olyan területi egységet értett, melyet hasonló társadalmi, földrajzi, gazdasági, politikai jellemzők kötnek össze. A megkérdezettek hangsúlyozták, hogy egy régió belsỏ kohézióját nagymértékben meghatározzák a közös érdekek, célok, valamint az emberek hasonló gondolkodása, mentalitása. Ez utóbbit - polgári mentalitás, befogadókészség, nyitottság - sokan említették, mint a Nyugat-dunántúli régió specifikumát (Nárai 1998). Ezzel szemben a lakosság körében végzett felmérés tapasztalatai egyrészt azt mutatják, hogy az emberek egy viszonylag meghatározó része nem tudja értelmezni a fogalmat - hatoduk nem válaszolt a kérdésre -; ami egyben azt is jelentheti, illetve úgy is értelmezhetó, hogy számukra az nem jelent semmit. Másrészt a kérdésre választ adók döntő többsége a régiót egyszerủen megyék összességeként értelmezi, ami alatt általában több megyére kiterjedő közigazgatási területet, földrajzi egységet, maximum gazdasági összefüggést, kapcsolódást értenek. Közösségitársadalmi szempontok, pl. az ott élók közös hagyományai, tradíciói vagy társadalmi, szociális hasonlósága minimális mértékben jelennek csak meg a régió fogalmának értelmezésénél ${ }^{4}$ (Pakainé Kováts-Bednárik 2009) (1. táblázat). Mindez nagyon jól mutatja, hogy a történelmi, kulturális hagyományok hiányában a lakosság számára a régió inkább közigazgatási, földrajzi kategória és nem társadalmi-történeti fogalom. Hasonló eredményeket kapott Murányi és Szoboszlai a Dél-alföldi régióban folytatott kutatásuk során (Murányi-Szoboszlai 2000).

Konkrétan a Nyugat-dunántúli régióra vonatkoztatva a kérdést, a regionális identitás szempontjából nem túl kedvező, hogy a megkérdezettek közel $40 \%$-a számára a Nyugat-dunántúli régió nem jelent semmit, saját életükre, érzéseikre vonatkoztatva nem tudják értelmezni ezt a területi kategóriát ${ }^{5}$. Gyakorlatilag ez azt jelenti, hogy az emberek igen magas hányada számára nem meghatározó vonatkoztatási keret a régió, e területi kategória az ismeretek szintjén bár valamilyen mértékben már jelen van (ismerik a régió nevét, esetleg tudják, hogy mely megyék tartoznak oda), de mélyebb (pl. emocionális) síkon még nincs, így nagy valószínűséggel kijelenthetjük, a régióval való azonosulásról, regionális identitásról ezen emberek esetében nem beszélhetünk.

Azok körében, akiknek a Nyugat-dunántúli régió jelent valamit, a régió többnyire pozitív asszociációkban jelenik meg, és elsősorban azt a helyet jelenti, ahol élnek, ahol dolgoznak (otthon, lakóhely, élettér, szülőföld, munka asszociációk fordultak elö minimum 5\%-os említési arányban). Érdekes módon azok a kategóriák, amelyekkel a régió fogalmának általános meghatározásánál találkozhattunk (megyék összessége, összefogása, földrajzi egység stb.) a konkrét régió értelmezésénél alig kerültek említésre (maximum 1-2\%-ban), inkább a személyesebb és szükebb kapcsolódások jelentek meg, kerültek előtérbe, melyek többsége érzelmi töltetet hordoz magában. 
Nárai Márta : Gondolatok a regionális identitásról. - Identitáselemek a Nyugat-dunántúli régióban.

Tér és Társadalom 23. évf. 2009/4. 137-159. p.

150 Gyors ténykép

TÉT XXIII. évf. 2009 - 4

\section{TÁBLÁZAT \\ A régió fogalmának értelmezése \\ (The Understanding of Region's Definition)}

\begin{tabular}{lc}
\hline \multicolumn{1}{c}{ Említések } & Gyakoriság (\%) \\
\hline Kettö vagy több megye összessége & 32,7 \\
Több megyét összefogó közigazgatási terület & 15,2 \\
Több megye tájegység/földrajz szerinti kapcsolata & 14,6 \\
Gazdaságilag összefüggö területek & 9,2 \\
Területi felosztás/egység, ami megyéken átnyúló, & 7,0 \\
megyék összevonása & 3,6 \\
Táj/tájegység, vidék/Magyarország valamely tájegysége & 2,4 \\
Statisztikai, tervezési, területfejlesztési egység & 1,3 \\
Megyék összefogása, szövetsége a lehetöségek legjobb & \\
kihasználása végett & 1,2 \\
Egy adott területen éló emberek csoportja, társadalmilag & 1,1 \\
összefüggő terület, emberi közösség & \\
Közösségek összetartozása, együttmüködése &
\end{tabular}

Forrás: Pakainé Kováts-Bednárik (2009, 25-26) alapján saját szerkesztés.

\section{Régióhoz való kötödés és a régió megitélése}

A regionális identitás meglétét sok esetben a térséghez való kötődés mértékével próbálják kifejezni. A kötődés mérése nem egyszerủ feladat, mértékét leginkább azzal tudjuk jellemezni, hogy mennyire szeretnek az emberek ott élni, büszkék-e vagy sem arra a területre, ahol élnek, mennyire vágyódnak el onnan. Másrészt a regionális identitás függ a lakosság elégedettségétól, perspektívatudatától is (Hegyi 2007); a régió pozitív megítélése, a régióval való elégedettség nagyban segíti a régiótudat kialakulását, fennmaradását, így ennek vizsgálata is egy fontos dimenzió.

A Nyugat-dunántúli régióban élök jelentős mértékben kötödnek lakóhelyükhöz, térséguikhöz. A 2000-es felmérés adatai szerint a megkérdezettek döntö többsége (88\%) szeret a régióban élni (6. ábra) (ötfokozatú skálán 4,36-os átlagérték), és nem gondolt arra, hogy máshová költözzön. Csupán a megkérdezettek 3\%-a tervezett lakóhely-változtatást, föként családi okokból, illetve munkavállalás miatt, de ôk is elsősorban a régión belül szándékoztak maradni. 
Nárai Márta : Gondolatok a regionális identitásról. - Identitáselemek a Nyugat-dunántúli régióban. Tér és Társadalom 23. évf. 2009/4. 137-159. p.

TÉT XXIII. évf. 2009 - 4

Gyors ténykép

\section{6. ÁBRA}

„Szeret Ön a Nyugat-dunántúli régióban élni?" kérdésre adott válaszok megoszlása, $2000(\%)$

(Share of the Answers on the Question: Do You Like Living in West-Transdanubian

Region?, 2000)

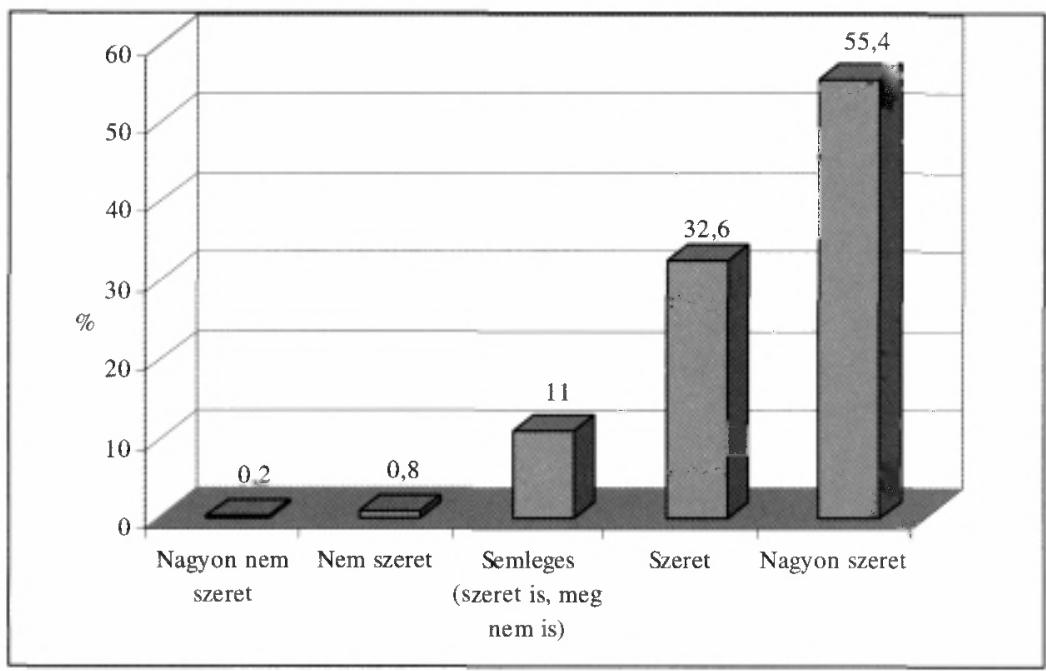

Forrás: Lakossági felmérés (2000).

\section{TÁBLÁZAT}

„Mi motiválja Önt abban, hogy a Nyugat-dunántúli régióban éljen?"

(What is your Motivation to Live in West-Transdanubian Region?)

\begin{tabular}{lc}
\hline \multicolumn{1}{c}{ Motiváló tényezők } & $\begin{array}{c}\text { Az egyes tényezöket } \\
\text { említook aránya (\%) }\end{array}$ \\
\hline Családi, rokoni kapcsolat & 94,2 \\
Baráti kapcsolat & 50,1 \\
Képzettségének megfelelö munkahely & 29,5 \\
A régiónak, mint tájnak, természeti környezetnek a & 29,1 \\
vonzereje & \\
Jó ellátási, szolgáltatási körülmények (kereskedelmi, & 25,9 \\
oktatási, szociális, egészségügyi stb. infrastruktúra) & 19,2 \\
A régió gazdasági vonzereje & 15,0 \\
Kedvezó szabadidő eltöltési lehetőségek & 7,0 \\
Gazdasági és egyéb vállalkozás & 7,0 \\
Egyéb & \\
\hline
\end{tabular}

Forrás: Lakossági felmérés (2000). 
Nárai Márta : Gondolatok a regionális identitásról. - Identitáselemek a Nyugat-dunántúli régióban. Tér és Társadalom 23. évf. 2009/4. 137-159. p.

A régióhoz való ragaszkodás kiemelkedően meghatározó tényezői a családi, rokoni ${ }^{6}$, valamint a baráti kapcsolatok, de jelentős motiváló ereje van a táji, természeti környezet vonzerejének és a képzettségnek megfelelő munkalehetöségnek is. A legkevésbé meghatározó tényezőknek viszont a rekreációs lehetőségek, gazdasági vagy egyéb vállalkozás, illetve a földhöz való kötődés bizonyultak (2. táblázat, 7. ábra). Kutatásunk e téren kapott eredményei többnyire összecsengenek a Dél-alföldi régióban tapasztaltakkal, ahol a régióhoz való rgaszkodás leginkább meghatározó elemeinek a környezet esztétikája, a lokálpatriotizmus, valamint a baráti, rokoni kapcsolatok, míg legkevésbé meghatározó elemeknek a szabadidő eltöltésének kedvező lehetösége és az anyagi jellegú feltételek hiánya (elköltözés pénzügyi fedezete, telek- és ingatlanárak) bizonyultak (Murányi-Szoboszlai 2000, 34).

\section{7. ÁBRA}

"Mihez érez kötödést a régióban?" - A kötödés erösségének mértéke ${ }^{x}, 2000$

(To What Extent Do You Bind to the Region? - The Rate of Strength of Binding)

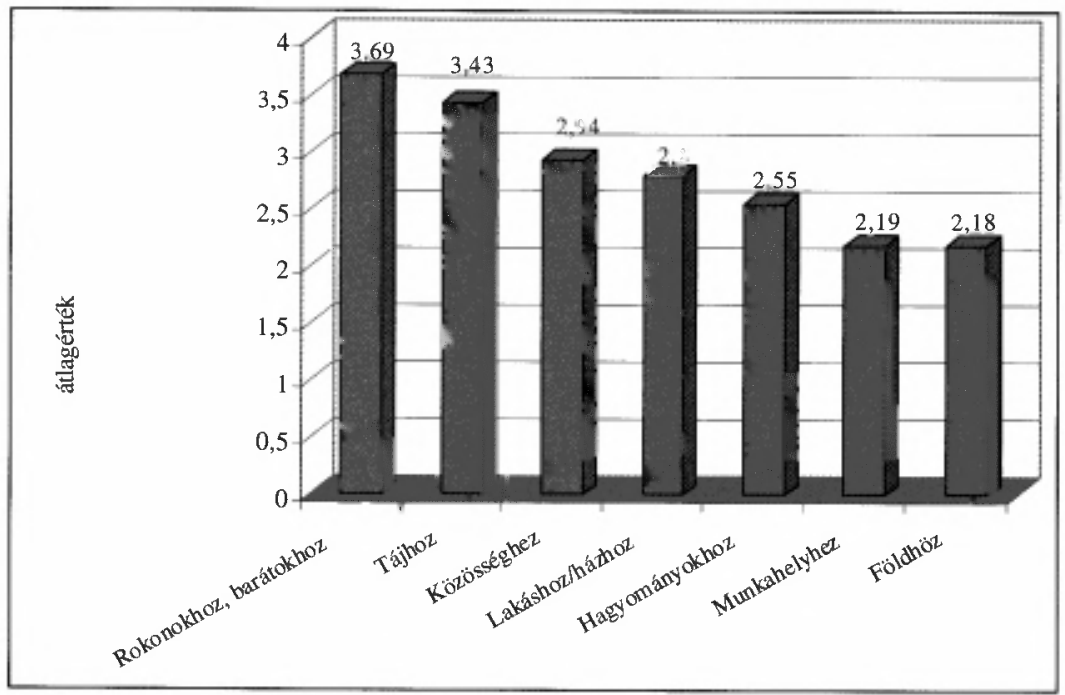

${ }^{x}$ Ötfokozatú skálán elért átlagok.

Forrás: Lakossági felmérés (2000).

Egy 2005-ben végzett kutatás eredményei is azt mutatták, hogy a NyugatDunántúlon élők az átlag felett kötődnek a régióhoz; a többi térségi kategória (település, megye, Dunántúl, Magyarország) mellett magas a régió preferenciája is (ötfokozatú skálán 4,5-ös átlagérték). A költözni szándékozók aránya akkor $9 \%$ volt, de többségük a régión belül kívánt lakóhelyet változtatni (A határmentiségtöl... 2005). Ezzel szemben a legfrissebb lakossági kutatás azt mutatja, hogy a megkérdezettek ötöde $(21,2 \%)$ elvágyódik lakóhelyéröl. A Dél-alföldi régióban a kilencvenes évek végén folytatott kutatás során hasonlóan magas arányt találtak: ha a lehetőségei engedték volna minden ötödik válaszadó elköltözött volna a lakóhelyéröl. Relatív 
Nárai Márta : Gondolatok a regionális identitásról. - Identitáselemek a Nyugat-dunántúli régióban. Tér és Társadalom 23. évf. 2009/4. 137-159. p.

többségük (38\%) régión belül változtatott volna lakóhelyet, de sokan (34\%) a Dunántúlra szerettek volna költözni (Murányi-Szoboszlai 2000).

A Nyugat-dunántúli régióban az évtized végén a lakóhelyükröl elvágyódókat tulajdonképpen három csoportra lehet bontani: 1) akiknek a költözésröl határozott elképzelései és tervei vannak $(6,6 \%) ; 2)$ akik szívesen elköltöznének, de nem látnak erre reális lehetóséget $(8,3 \%)$; és 3$)$ azok, akik a távoli jövőre teszik az elköltözés idejét $(6,3 \%)$. A régiót alkotó egyes megyékben élők véleményében nem volt szignifikáns különbség, az életkor és az iskolai végzettség alapján viszont meghatározó különbségek adódtak az elköltözési szándékot illetően (Pakainé Kováts-Bednárik 2009). A fiatalok körében lényegesen erősebb a költözési szándék, a 35 év alatti válaszadók közül minden harmadik elköltözne jelenlegi lakóhelyéről, tizedüknek határozott tervei vannak. Ezzel szemben a 36-55 évesek 14\%-a, az 55 évesnél idősebbeknek pedig csupán $8,2 \%$-a foglakozik a lakóhely-változtatás gondolatával; a költözést határozottan tervezők mindössze 3,5\%-nyian vannak mindkét korcsoportban. Ez egyben azt is jelenti, hogy a költözni szándékozók között lényegesen felülreprezentáltak a fiatalok: míg a 35 éven aluliak mintán belüli aránya 44,5\%, addig a költözést fontolgatók minden csoportjában ennél jóval magasabb arányt, abszolút többséget képviselnek (a költözést határozottan tervezők $69,4 \%$-át, a költözést a távoli jövőben realizálók 78,3\%-át, a 'költözne, de nincs rá lehetősége' csoport 58,7\%-át a nevezett korcsoportba tartozók teszik ki).

Az iskolai végzettséget tekintve elmondható, hogy a diplomások, illetve az érettségizettek több mint $70 \%$-a nem költözne el jelenlegi lakóhelyéröl, a maximum szakmunkásvégzettséggel rendelkezök körében kicsit alacsonyabb $(67 \%)$ ez az arány. Ez utóbbiak körében viszonylag magas $(12,2 \%)$ azoknak az aránya, akik elköltöznének, ha lenne erre lehetöségük. Az e csoportba tartozók között egyébiránt felülreprezentáltak is az alacsonyabb iskolai végzettségủek: az e kategórián belüli arányuk $38,2 \%$ szemben a teljes mintán belüli $26 \%$-os arányukkal.

A lakóhely-változtatást fontolók egy jelentős része (kb. 30\%-a) a 2008-as felmérés tapasztalatai szerint is a régión belül maradna, de nagyon magas (52\%) a külföldre vágyók aránya, ami korábban szinte alig volt jellemző. Ez mutatja azt is, hogy a válaszok mögött (azaz, hogy olyan sokan elköltöznének, ha tehetnék) nem elsősorban a régiótól való elpártolást, hanem a Magyarországgal szembeni jelenlegi általános elégedetlenséget lehet sejteni, ami főként a fiatalokat motiválja arra, hogy az országon kívül reméljék, keressék boldogulásukat. A legtöbben egyébiránt a jobb munkalehetöség, jobb kereseti lehetőségek miatt szeretnének külföldre költözni.

Az elvágyódók magasabb aránya ellenére napjainkban is azt mondhatjuk, hogy a régió lakosai szeretnek itt élni és többségüket $(68,3 \%)$ büszkeség tölti el a régiót illetően (8. ábra). A régióhoz való kötődés erősségét, a régióval való elégedettséget mutatja az is, hogy a válaszadók háromnegyede $(72,7 \%)$ azt szeretné, ha gyermeke is a Nyugat-dunántúli régióban telepedne le. A 2008-ban folytatott kutatás tapasztalatai szerint a Nyugat-dunántúli régióban élők legbüszkébbek arra, hogy a Dunántúlon élnek, ezt követi a megyére és a régióra, valamint a településre való büszkeség, melyek ,mértékében” nincsenek jelentős eltérések (9. ábra). 
Nárai Márta : Gondolatok a regionális identitásról. - Identitáselemek a Nyugat-dunántúli régióban.

Tér és Társadalom 23. évf. 2009/4. 137-159. p.

\section{8. ÁBRA}

„Büszke arra, hogy a Nyugat-dunántúli régióban él?" (\%)

(Are You Proud of Living in West-Transdanubian Region?)

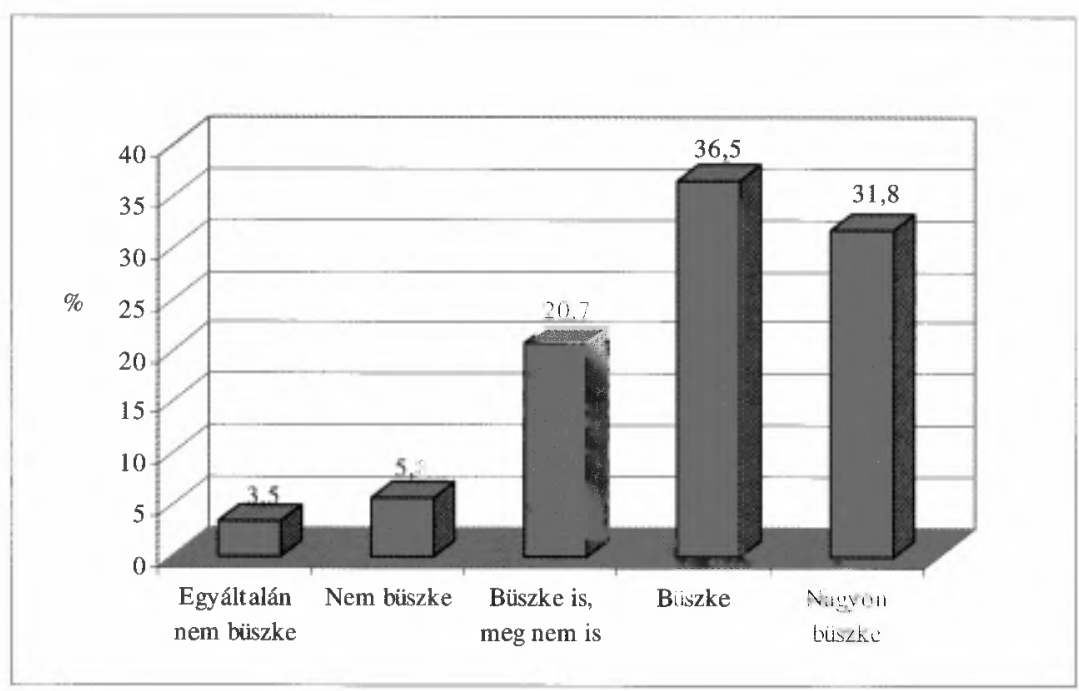

Forrás: Pakainé Kováts-Bednárik $(2009,30)$ alapján saját szerkesztés.

\section{9. ÁBRA}

"Mennyire büszke arra, hogy..."

(How Proud Are You of...)

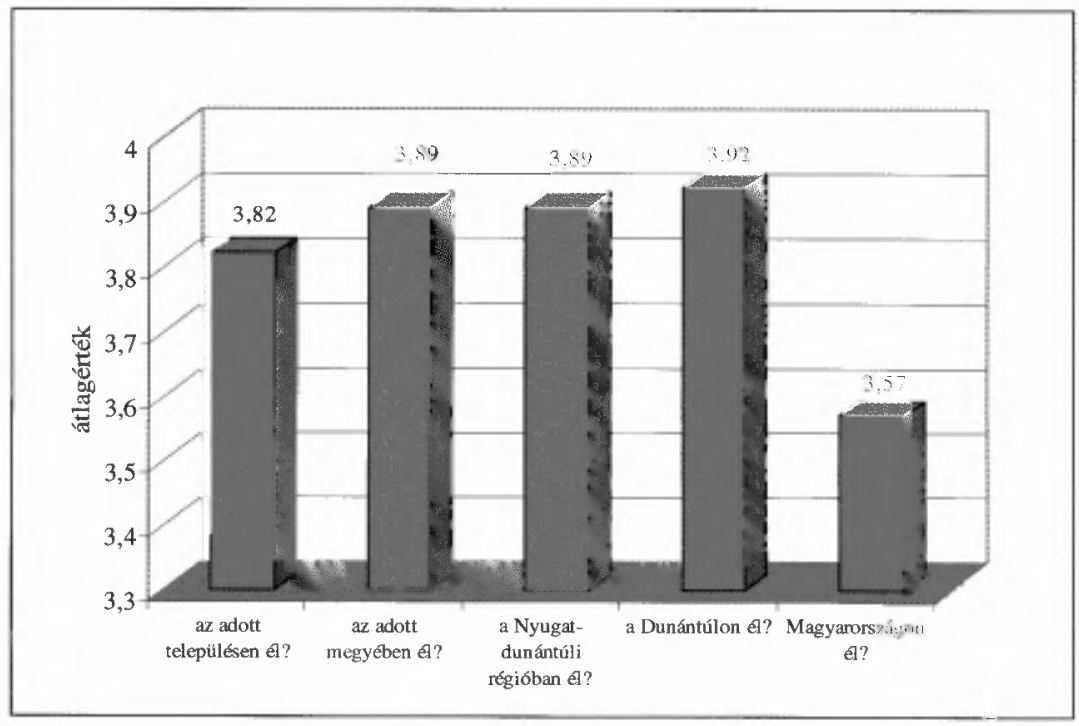

Megjegyzés: Ötfokozanú skálán elért átlagértékek.

Forrás: Pakainé Kováts-Bednárik $(2009,27)$ alapján saját szerkesztés. 
Nárai Márta : Gondolatok a regionális identitásról. - Identitáselemek a Nyugat-dunántúli régióban. Tér és Társadalom 23. évf. 2009/4. 137-159. p.

Legtöbben a természeti környezetre és a munkalehetőségekre ${ }^{7}$, illetve az országos átlagnál magasabb életszínvonalra büszkék a régióban, de említésre kerülttek még 5\% alatti arányban - többek között a termál- és wellnesfürdők, az idegenforgalom, a fejlett ipar, a kulturális élet is. A régió megítélése alapvetôen pozitív, a válaszadók többsége (kétharmada) az ország többi régiójához viszonyítva jobb vagy sokkal jobb helyzetúnek ${ }^{8}$ tartja a térséget, ugyanakkor csupán a megkérdezettek kisebb része $(38,5 \%)$ vélekedik úgy, hogy a Nyugat-Dunántúl a lehetőségek régiója. Viszonylag kedvezőtlen értékelést kapott a régió a lakosság vidámságát, a fejlődést és a pozitív jövőképet illetően. Az értékelések átlaga pozitív önképet mutat viszont a vendégszeretet és a befogadás tekintetében (Pakainé Kováts-Bednárik 2009) (10. ábra).

\section{0. ÁBRA}

„Mennyire jellemzó a Nyugat-dunántúli régióra, hogy...?",

(How Typical is it for the West-Transdanubian Region?)

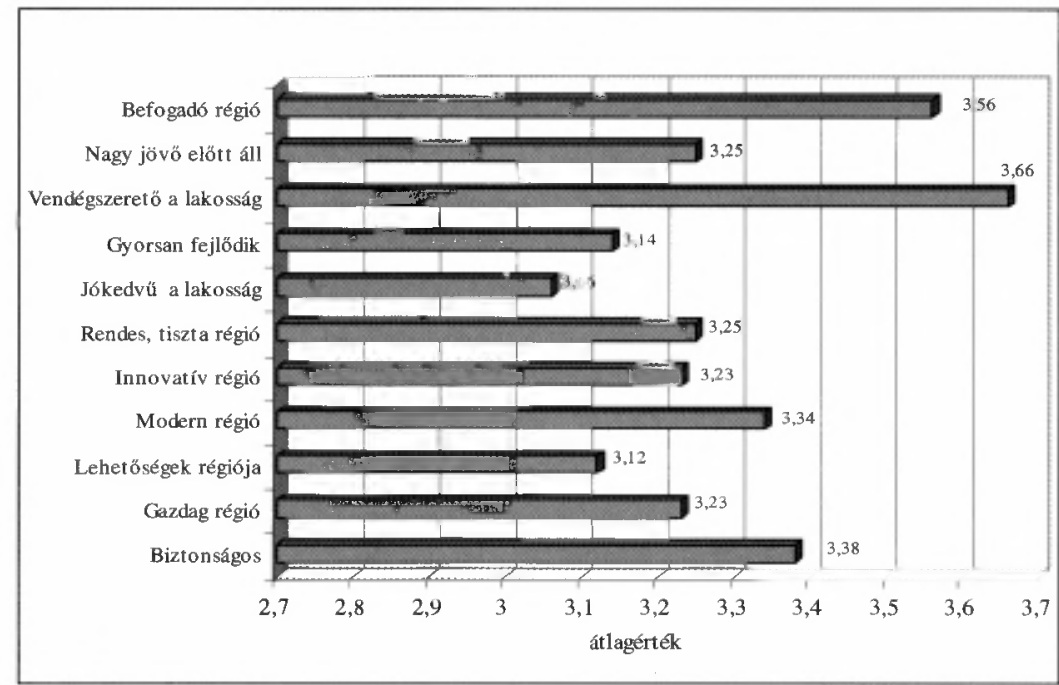

`Átlagértékek, a vizsgált tényezőket ötfokozatú skálán értékelték a megkérdezettek.

Forrás: Pakainé Kováts-Bednárik $(2009,56)$ alapján saját szerkesztés.

A régió megítélése során vizsgálták azt is, hogy különbözö, a regionális összetartozást, kohéziót megjelenító tényezóknek milyen a jelenléte a Nyugat-dunántúli régióban. Mennyiben jellemző a térségre pl. a földrajzi összetartozás, a közös sors, a közös tradíciók, közös célok, vagy akár a gazdasági szereplök együttműködése?

A válaszok átlagértékei nem egy erős kohézióval rendelkezỏ régióról árulkodnak. A legjellemzőbbnek tartott tényezők esetében is rendre négy alatti átlagértékek adódtak, ami azt jelenti, hogy a válaszadók legnagyobb része szerint csupán közepes mértékben, illetve részben jellemzőek e megállapítások a Nyugat-dunántúli régióra. Csupán a földrajzi összetartozásról gondolták úgy sokan (24\%), hogy az teljes mértékben jellemző a térségre. A megkérdezettek szerint leginkább egyébiránt a területek földrajzi összetartozása, a közös sors és a jó megközelíthetőség, 
Nárai Márta : Gondolatok a regionális identitásról. - Identitáselemek a Nyugat-dunántúli régióban. Tér és Társadalom 23. évf. 2009/4. 137-159. p.

legkevésbé pedig az jellemző a régióra, hogy az itt élök közös célokkal rendelkeznek, és az itt található cégek a lehetőségeket kihasználva együttmüködnek. A Zala megyeiek kevésbé érzik a belső kohéziót, ugyanis valamennyi tényezöt kevésbé jellemzőnek tartották a másik két megye lakosaihoz képest (Pakainé KovátsBednárik 2009, 39-46). Az egyes tényezők megítélését a 3. táblázat mutatja.

\section{TÁBLÁZAT}

A regionális összetartozást, kohéziót megjelenítö tényezők jelenlétének megítélése (The Judgement of Presence of Factors Indicating Regional Cohesion)

\begin{tabular}{lc}
\hline \multicolumn{1}{c}{ Tényezök } & Átlagérték $^{x}$ \\
\hline A területek földrajzi összetartozása & 3,64 \\
Közös sors, történelem & 3,47 \\
A területek jó megközelíthetősége & 3,40 \\
Az itt élők közös hagyományai, tradíciói & 3,33 \\
Az itt élök társadalmi, szociális hasonlósága & 3,02 \\
Az itt élők közös érdekkel, célokkal rendelkeznek & 2,93 \\
A régióban található cégek közös gazdasági kapcsolatai & 2,88 \\
\hline
\end{tabular}

“Ötfokozatú skálán mérve.

Forrás: Pakainé Kováts-Bednárik $(2009,40)$ alapján saját szerkesztés.

\section{Összegzés}

A területi-térségi identitást a társadalmi identitástudat szerves részeként értelmezzük, mely alapján az egyén a személyes kapcsolathálónál tágabb, földrajzi kategóriákkal (pl. település, kistérség, megye, régió) meghatározható társadalmi csoport tagjának érzi és vallja magát. A regionális identitás is elsősorban a hovatartozással és az azonosulással kapcsolatos emocionális és kognitív mintákat tartalmazó kommunikációs együttes, szocializációs fejlemény, melyet társadalmi és történeti tényezők generálnak és formálnak, a régiós reprezentációra irányuló diakron és szinkron kommunikációs mechanizmusok alakítanak (Murányi-Szoboszlai 2000).

Tapasztalataink szerint egy térséghez való kötődés kialakulásában, fennmaradásában elsódleges szerepet játszik a családi, rokonsági kapcsolatok térségen belülisége, a földrajzi környezet karakterisztikus és vonzó volta, a boldogulási lehetöségek milyensége (pl. munkalehetőségek), de a helyben lakás/ott élés időtartama, a saját tulajdon megléte (ház, lakás, föld), vagy a térség hagyományai, azok ápolása sem elhanyagolható tényezők. Történeti, kulturális hagyományok hiányában azonban a tényleges regionális identitás, öntudat kiépítése, kiépülése rendkívül hosszú időt igénybe vevő folyamat, aminek még csak az elején tartunk, ezt jelzi az is, hogy az emberek számára a régió ma még elsősorban közigazgatási, földrajzi kategória és nem társadalmi-történeti fogalom. 
Nárai Márta : Gondolatok a regionális identitásról. - Identitáselemek a Nyugat-dunántúli régióban. Tér és Társadalom 23. évf. 2009/4. 137-159. p.

Bár magas a Nyugat-Dunántúlon a régióhoz való kötődés mértéke, az emberek többsége szeret itt élni, büszke a térségre, azonban nem alakult ki még erős belső kohézió, összetartozás érzés. A regionális identitásnak már megvannak a jelei, de szintje, mértéke még mérsékelt. A már kibontakozó regionális gondolkodás azonban arra is utal, hogy tudatos építkezéssel az adott regionális határok kitölthetők tartalommal. Csak így érhető el, hogy a régióépítés Paasi (2001) által leírt folyamatában a Nyugat-Dunántúl egyre előrébb jusson, hiszen abból napjainkig - teljes mértékben mindössze a régió területi struktúrájának kialakítása történt meg. Mind a közös szimbólumok megformálása, mind az együttműködések kialakítása, kapcsolatformálás tekintetében vannak még kiaknázatlan lehetőségek, vannak még teendők, amelyek „végrehajtása” mindenképpen szükséges ahhoz, hogy a fizikai térből igazi, regionális identitással bíró régió váljék.

Ilyen feladatnak tekinthető pl. a megfelelő szimbólumrendszer megformálása, amely - annak ellenére, hogy a regionális identitás lényegét nem a szimbólumok jelentik mégis - kiemelkedő jelentőségü a régió identifikációs folyamatában. A jól megválasztott, jól kitalált szimbólumok kifejezik a régió egységét és segítenek az összetartozás, a közös tudat formálódásában. Ưgy tủnik azonban, hogy a Nyugatdunántúli régióban ezek egyelöre nem igazán töltik, tölthetik be a régióépítésben lényegi funkciójukat, e megállapításunkat arra alapozzuk, hogy a régió logója és szlogenje csak kevesek által ismert. Tapasztalataink szerint azzal is csak kevesen vannak tisztában, hogy müködnek olyan intézmények, szervezetek (pl. Regionális Fejlesztési Tanács, Regionális Fejlesztési Ügynökség) ${ }^{9}$, amelyek tevékenysége az egész régióra kiterjed.

A megfelelő szimbólumok megtalálása mellett, amelyek nemcsak tárgyak lehetnek, hanem pl. olyan személyek is, akik itt éltek/élnek, itt alkottak/alkotnak és akikre, vagy akik eredményeire a többség büszke, hangsúlyoznunk kell a tényleges társadalmi, kulturális, gazdasági együttmüködések, illetve különböző közös események (legyen az akár sportesemény, kulturális rendezvény, fesztivál stb.) fontosságát, amelyek egyrészt összehozzák az itt élőket, másrészt kifejezik az összetartozást. Ezen események, kapcsolatok, együttmüködések adják meg az alapját a regionális identitásnak, általuk teremtődhet meg, illetve erősödhet, fejlődhet tovább a régión belüli kohézió.

Ahhoz azonban, hogy ezek megszervezödhessenek, meg kell találni azokat a közös pontokat, célokat, ügyeket, illetve érdekeket, amelyekben az itt élők egyetértenek, amelyeket követni, elérni, illetve érvényesíteni szándékoznak, amelyek öszszetarthatják a régió lakosságát, más társadalmi szereplőit. Az empirikus felmérések szerint a legnépszerủbb közös ügy a különböző fejlesztések és az azokban rejlö lehetőségek kihasználása (a válaszok 26,3\%-a valamilyen [gazdaság, infrastruktúra stb.] fejlesztésre vonatkozott), ezen belül markánsan megjelenik a közlekedésfejlesztés (É-D autópálya), az úthálózat fejlesztése, továbbá a munkahelyteremtés (22\%), valamint az idegenforgalom erősítése (6\%). De felmerült a hagyományápolás, a közös kulturális rendezvények szervezése, a környezetvédelem, az oktatás és az egészségügy is (Pakainé Kováts-Bednárik 2009, 149). 
Nárai Márta : Gondolatok a regionális identitásról. - Identitáselemek a Nyugat-dunántúli régióban. Tér és Társadalom 23. évf. 2009/4. 137-159. p.

A közös célok megtalálása, illetve a szimbólumok megalkotása azonban csak egyegy állomás a régióépítés folyamatában, hogy ezek mindenkihez elérjenek, hogy lényegi funkciójukat ki tudják fejteni, elengedhetetlen és alapvető a megfelelö kommunikálásuk. A regionális szereplöknek, intézményeknek mind a tömegkommunikációs eszközök, mind az oktatási rendszer segítségével törekedniük kell a régióval kapcsolatos ismeretek terjesztésére, a régió valódi ismertségének a növelésére. Ennek azonban nem kampányszerü imázsépítésnek kell lennie, hanem folyamatos imázs-formálásra, tudatos identitás-építésre van szükség.

\section{Jegyzetek}

${ }^{1}$ A speciális tényezők (pl. fejlett infrastruktúra, kvalifikált, konvertálható tudású munkaerő) hiányában azonban szinte teljes egészében hiányoznak azok az iparágak, amelyek a fejlődés motorjai lehetnének. Ezek a régiók erős identitásuk ellenére általában kevés versenyelönnyel rendelkeznek, ami mutatja, hogy önmagában a regionális identitás nem elegendö sikertényezö, de megfelelö gazdasági feltételek esetén hozzájárul azok kiaknázásához tovább növelve a régió sikerességét.

2 A regionális identitás mértékének meghatározása nem egyszerü feladat, a téma empirikus kutatásának nincs kidolgozott módszertana, nincsenek hosszú távra visszatekintő hagyományai, azonban történtek törekvések e kérdéskör operacionalizálására, mérésére - nem feltétlenül önálló kutatások keretében (pl. Murányi-Szoboszlai 2000; A határmentiségtől... 2005; Pakainé Kováts-Bednárik 2009).

${ }^{3}$ Az egyetemet végzettek körében $100 \%$-ot ért el a helyesen válaszolók aránya.

${ }^{4}$ Egy másik, a régió megítélését konkrét kategóriákban mérö kérdésre adott válaszok átlaga szerint is a régióra leginkább a területek földrajzi összetartozása jellemzö, e tényező kapta a legmagasabb átlagértéket (ötfokozatú skálán 3,64). Jóval kevésbé tartották jellemzőnek a válaszadók a régióra az itt élők társadalmi, szociális hasonlóságát (átlag 3,02), vagy akár a közös hagyományokat (átlag 3,33) (Pakainé Kováts-Bednárik 2009).

5 A megkérdezettek 15,5\%-a határozottan kijelentette, hogy a régió számára nem jelent semmit, 23,4\%-uk pedig nem válaszolt a kérdésre (Pakainé Kováts-Bednárik 2009, 36). A véleményhiányt gyakorlatilag úgy értékelhetjük, mintha nem jelentene a régió a nem válaszoló megkérdezett számára semmit, mivel feltételezzük, hogy valamiröl azért nincs valakinek mondanivalója, mert az a valami nem fontos, nem meghatározó az életében.

${ }^{6}$ A 2000-ben folytatott lakossági felmérés során megkérdezetteknek csupán a 27\%-a jelezte azt, hogy családi kapcsolatai csak részben vannak a Nyugat-dunántúli régióban, közel háromnegyedüknek a rokoni kötelékei kizárólag a régióra koncentrálódtak.

${ }^{7}$ A munkalehetőségek kérdése megosztja a válaszadókat, ugyanis nagyjából annyian említették a munkalehetőségek hiányát a „Mire nem büszke a régióban?” kérdésre adott válaszaikban, mint ahányan büszkék a jó munkalehetôségekre. A válaszadók még az utak rossz állapotát, a környezetvédelem, a hulladékkezelés nem megfelelö voltát, valamint a kisebbségi problémákat említették 5\% feletti arányban (Pakainé Kováts-Bednárik 2009, 34-35).

A megkérdezettek 59\%-a vélekedik úgy, hogy a többi régióhoz képest jobb helyzetben van a NyugatDunántúl, és csupán 7,4\% azok aránya, akik szerint sokkal jobb helyzetben van. A válaszadók $27 \%$-a szerint a többiekhez hasonló helyzetben van (Pakainé Kováts-Bednárik 2009, 130).

A 2008-ban folytatott kutatás eredményei szerint a Nyugat-dunántúli Regionális Fejlesztési Tanácsról a megkérdezettek $18 \%$-a, a Fejlesztési Ügynökségröl $23 \%$-a még soha nem hallott, és ha hallott is, 62-63\%-uk nem ismeri azok munkáját (Pakainé Kováts-Bednárik 2009). 
Nárai Márta : Gondolatok a regionális identitásról. - Identitáselemek a Nyugat-dunántúli régióban. Tér és Társadalom 23. évf. 2009/4. 137-159. p.

\section{Irodalom}

Agg Z.-Nemes Nagy J. (2002) A politika térségi és helyi szintjei. - Bernek Á. (szerk.) A globális vilag politikai földrajza. Nemzeti Tankönyvkiadó, Budapest. 385-430. o.

Blotevogel, H.H.-Heinritz, G.-Popp, H. (1989) „Regionalbewusstein”- Zum Stand der Diskussion um einen Stein Anstosses. - Geographische Zeitschrift. 2. 65-88. o.

Bokor B. (é.n.) regionális identitás, kultúra és közösség. - Tudásmenedzsment. PTE Felnöttképzési és Emberi Eröforrás Fejlesztési Kar, Pécs. http://feek.pte.hu/tudasmenedzsment/index.php?ulink=1141 Letöltve: 2009.03.09.

Bourdieu, P. (1985) The Social and the Genesis of Groups. - Socialscienen Information. 2. 195-220. o.

Böhm A. (2000) Térségi identitás. - Horváth Gy.-Pálné Kovács I. (szerk.) Területfejlesztés és közigazgatás-szervezés. MTA, Budapest. 111-127. o.

Böhm A. (2002) Lokális és regionális identitás. - Comitatus. 4. 29-34. o.

Faragó L. (2007) Térstruktúra: Térideák és megvalósításuk a településhálózat-fejlesztésben. - Tér és Társadalom. 4. 21-38. o.

Garai L. (1998) Emberi potenciál, mint tôke: bevezetés a gazdaságpszichológiába. Aula, Budapest.

Garai L. (2003) Identitásgazdaságtan. TAS Kiadó, Budapest.

Hankiss E. (2005) Transznacionális identitásképzés a Nyugat-Pannon Eurégióban. Ausztria Magyarország Phare CBC program. Köszegi Európai Egyetemi Intézet, Köszeg. 28-32. o.

A hatârmentiségtól az integrált határrégióig. (2005) Kutatás a PHARE CBC 2002 program támogatásával. MTA RKK NYUTI, Györ.

Hegyi F.B. (2007) Regionális identitás. - Rechnitzer J. (szerk.) Nyugat-Dunántúl. MTA RKK, PécsBudapest. XIV. fejezet. 387-400. o.

Ipsen, D. (1993) Regionale Identität - Raumforschung und Raumordnung. 1. 9-18. o.

Landaboso, M. (2003) The Role of Social Capital in Promoting Competitiveness in Less Favoured Regions: Policy Options in Perspective. http://www.ebms.it/SS/background_paper.pdf Letöltve: 2009.03.15.

Lengyel I. (2000) A regionális versenyképességről. - Közgazdasági Szemle. 12. 962-987. o.

Lengyel I.-Rechnitzer J. (2004) Regionális gazdaságtan. Dialóg Campus, Budapest-Pécs.

Lukovics M. (2004) A regionális identitás szerepe a regionális gazdaságfejlesztésben. - Czagány L.Garaî L. (szerk.) A szociális identitás, az információ és a piac. SZTE Gazdaságtudományi Kar Közleményei. JATE Press, Szeged. 214-228. o.

Murányi I.-Szoboszlai Zs. (2000) Identitás-jellemzök a Dél-alföldi régióban. - Tér és Társadalom. 1. 27-50. o.

Nárai M. (1998) Nyugat-Magyarország belsổ kohéziója. Esettanulmány. Györ. Kézirat.

Nemes Nagy J. (2009) Terek, helyek, régiók. A regionális tudomány alapjai. Akadémiai Kiadó, Budapest.

Pakainé Kováts J.-Bednárik É. (2009) Nyugat-dunántúli Regionális Fejlesztési Tanács és Ügynökség marketingstratégiát megalapozó regionális identitáskutatás. Nyugat-dunántúli Regionális Fejlesztési Ügynökség, Sopron.

Paasi, A. (2000) Re-constructing regions and regional identity. http://www.kun.nl/socgeo/n/colloquium/ Paasil.pdf. Letöltve: 2009.03.09.

Paasi, A. (2002) Regional Transformation in the European Context: Notes on Regions, Boundaries and Identity. - Space \& Policy. 2. 197-201. o.

Paasi, A. (2003) Region and Place: regional identity in question. - Progress in Human Geography. 4. 475-485. o.

Palkó K. (2009) Regionális identitás - adalékok egy fogalom tisztázásához. - Buday-Sátha A.-Erdös K.Komlósi É. (szerk.) Evkönyv 2009. Pécsi Tudományegyetem Közgazdaság-tudományi Kara Regionális Politika és Gazdaságtan Doktori Iskola, Pécs. 196-207. o.

Raagmaa, G. (2002) Regional identity in Regional Development and Planning. - European Planning Studies. 1. 55-76. o.

Szörényiné Kukorelli I. (1998) A Nyugat-dunántúli régió - régió? - Tér és Társadalom. 3. 51-77. o.

van Houtum, H.-Lagendijk, A. (2001) Contextualising Regional Identity and Imagination in the Construction of Polycentric Urban Regions: The Cases of the Ruhr Area and the Basque Country. Urban Studies. 4. 747-767. o.

Varró K. (2004) A régió mint diszkurzív termék. - Tér és Társadalom. 1. 73-91. o. 